\title{
Personalized College English Teaching Based on Collaboration among Teachers
}

\author{
Hua You \\ ${ }^{1}$ School of Applied English Studies, Shandong University of Finance and Economics, China \\ Correspondence: Hua You, School of Applied English Studies, Shandong University of Finance and Economics, \\ Jinan, Shandong, China 250014. Tel: 86-138-5312-1379. E-mail: 86521252@qq.com
}

Received: April 29, $2015 \quad$ Accepted: June 14, $2015 \quad$ Online Published: July 2, 2015

doi:10.5430/ijelt.v2n2p40 URL: http://dx.doi.org/10.5430/ijelt.v2n2p40

\begin{abstract}
In college English teaching, students' individualization requires teachers to adopt a personalized mode of teaching with their own unique style. And personalized mode of teaching, if based on collaboration among teachers, can achieve a better teaching effect. Based on the analysis of the differences in students' individualization and the theory of construction, this thesis puts forward three personalized college English teaching modes and four approaches to teachers' collaboration.
\end{abstract}

Keywords: individualization, personalized teaching, collaboration

\section{Introduction}

For quite a long time, the unified teaching management, the same textbooks, syllabuses and course wares, plus the single mode of teaching have been attached importance to in college English teaching. The single mode of teaching lacks individualization and style, ignoring the already existing differences among students, greatly harming students' interest in English study, limiting students' personality development, and strangling teachers' originality and cooperation as well. Students' individualization requires English teachers to adopt a unique mode of teaching. But how to eliminate the "the collective will"and "the unified conception" so as to achieve a personalized, diversified and effective English teaching? The author believes that the key to this problem is that English teachers should carry out personalized mode of teaching based on their collaboration.

\section{Students' Individualization Requires English Teachers to Take Unique Mode of Teaching}

\subsection{Personalized Teaching}

Personalized teaching in English class means that teachers should combine their classroom teaching with students' individualization so that they can adopt flexible and versatile teaching methods, with the students as the centre and the teacher as the guider. Thus, teachers can carry out personalized teaching, provide a better study environment and condition for the students, promoting their initiative and activeness in study and giving a full play to their potential. Meanwhile, as I see it, personalized teaching also refers to the unique teaching style of the teacher, which is not a teaching method, but a teaching conception, a combination of professional knowledge with personal qualities. If the students are in favor of the teacher's particular teaching style, their interest in English study will intensify and they will concentrate more in class. In this way, the students' motive in English study will become stronger, and their potential will be aroused more easily.

\subsection{Theories for Personalized Teaching}

College English Curriculum Requirements has advocated many times that individualized learning, with construction theory as its theoretical base, should be fully demonstrated in the course design. Constructivists stress how the learners construct knowledge in their thinking frame, with psychologist Piaget (1972) as the representative figure, who believed that creatures have the ability to adapt to the environment and form their mentality and behavior through accommodation and assimilation during the process. Based on Piaget's theory, psychologist Kelly (1963) put forward the notion of Personal Constructs, emphasizing that each individual has different personal constructs that he 
uses to deal with a learning task. Taking language learning for example, a learner should be aware of their own personal constructs and the studying process. With this in mind, one of the important findings is to create meaningful learning environment and learning materials. The learner should learn to construct his own learning space. Cohen (1998) has been applying the above principle to the teaching of foreign languages. He Emphasizes learners' own preference of learning style and learning strategies should be respected. For instance, some learners prefer the visual approach, some the oral approach, and some the hand-on approach. There is no point for the teacher to interfere with their choices. Every learning style and strategy can achieve a good learning effect and teachers should respect students' choices.

There may be various reasons for students' individualization. First of all, such non-intellectual factors as motive, will, personality, major, interest and so on are the main reasons, which tend to be ignored in college English teaching nowadays; secondly, college English teaching involves different linguistic skills, and the different demands for linguistic skills must be demonstrated in individual's personal construct; thirdly, learning evaluation is usually systematic, but students' self-evaluations differ from each other due to the differences in learning goals and capabilities. Consequently, students will learn what they need according to their own demand and individual traits. And they will contempt or be fed up with the same textbooks, the same teacher and the same teaching methods.

\subsection{Personalized English Teaching}

\subsubsection{Build up Grading Teaching System Based on Students' Individualization}

Students' individualization requires that college English teaching proceed from reality and stick to grading teaching. There must be differences in each student's language learning, which mainly lie in their cognition of language study, emotional states, age, language learning ability, motive, character, and so on. And because of their different experiences in English study before they enter university, they differ in language level and language skill, such as reading, speaking, writing and translating. The mode of grading teaching, which emphasizes teaching according to each student's merits, can strengthen the training of students' comprehensive English application, and improve their ability in listening and speaking. The key to grading teaching is try to be as clear as possible about student's individual differences shortly after they enter university. So the school needs to give a placement test to find out or estimate their English level. In our university, those who perform as top students will be placed in the experimental classes and specially assigned teachers of good teaching competence will take charge of them, using different textbooks and of course, different teaching methods as well. And to cater to the students' capability, additional subjects are added in the curriculum. This is one form of grading teaching anyway. In practical English teaching, teachers should get to know the relevant information of each student about English study through talking and questionnaires, such as English level, motive, learning strategy, and how they feel about English learning. Then, teachers can help students set their learning goals, make practical study plans, and cultivate their self-control and self-study ability through various methods to enhance their ability in the study and comprehensive application of English and fully stimulate their potential.

In the past National College English competition this year, there were altogether 14 students who won the special and first prizes, four of them are from the experimental classes.

\subsubsection{Combine Web-based Teaching with Teachers' Face to Face Teaching}

With the advanced information technology and the wide use of the internet, English teachers should make full use of the multimedia network, improve their teaching methods and build a curricular system and teaching model fit for individual development. With a large enrollment of college students, teachers can take advantage of modern teaching facilities and multimedia network with the aid of computer networking technology, carry out viewing, listening and speaking practice, thus enriching classroom activities and contents, and arousing students' interest in English study.

Give autonomous learning classes so that students can study the text, the grammar and language points on the computer with their own choices. In the past, big-class teaching was wide-spread in college English teaching, and it was impossible to carry out classroom interaction. As a result, teachers were basically cramming in the class, which was hard, yet didn't achieve a good teaching effect, thus English classroom teaching has gradually drifted away from students' need. While in the new mode of classroom teaching, teachers' cramming has been replaced by students' participation and self-study. After they grasp the key points in teaching using teaching software, students will have a deeper understanding at the linguistic level, and they will go to class with the difficult points or questions they meet in learning. Consequently, the key points in teaching should change in response, that is to say, passage analysis should give way to classroom discussion and classroom activities. In this way, students will have the opportunity to get involved in classroom teaching and listen to other students' opinions, so as to broaden their horizon. Furthermore, 
listening and speaking class can also adopt the mode in which students' autonomous learning is combined with teachers' face to face teaching. With the detailed explanation for the text by the teaching software, students surely can communicate with their teachers while learning on the computer or on line, realizing autonomous learning. Firstly, students study in fixed time periods with the viewing, listening and speaking teaching software on the computer, then teachers give small-class teaching on what they have studied and guide their learning progress, strengthening what they have learned and carry out practical classroom activities, such as role play, dialogue, situation setting, talking about pictures, games, and so on to better enhance students' ability in comprehensive application of English.

\subsubsection{Develop Unique Teaching Style and Try Personalized Teaching}

Scholars still differ in the definition of unique teaching style, but they all believe that it is shaped after a long time of teaching practice and life experience. Teaching style is closely related to teachers' personality, which is a teaching approach under the guidance of a certain teaching concept, a unique combination of teaching pattern, teaching methods and teaching techniques. Teaching style in modern classes can be divided into the following types according to the different ways in teacher-student communication, that is, intellectual, emotional, humorous, elegant, intuitive, singular, and so on. Teachers' teaching style is gradually formed after a long time of exploration. There are many factors contributing to the formation of it, mainly including knowledge, ability, psychology, experience, subjective and external conditions, etc. It's a long and hard process for teachers to start teaching, grow up and finally form their own teaching styles, during which, they need to imitate and borrow ideas from experienced teachers, then create, reflect and re-create their own teaching style, so as to demonstrate their uniqueness in each teaching stage. Teaching with a unique style will help students mobilize their initiative. Apart from the unique teaching style, English teachers should try web-based personalized teaching, for example, building their own teaching blogs, using communicative tools such as QQ, Wechat, etc., which forms a close connection between the teach and the students. If there is any problem, they can communicate with each instantly.

\section{Personalized College Teaching Should Be Based on Teachers' Collaboration}

To carry out high-quality personalized teaching, college English teachers should collaborate with each other, for personal strength is far from enough. What's more, as the working load becomes heavier and heavier, and scientific research becomes a burden, college English teachers find it hard to prepare lessons efficiently.

\subsection{The Necessity for Teachers' Collaboration}

Teachers differ greatly in their knowledge structure, intelligence level, cognitive style, and so on. Consequently, there are differences in dealing with the teaching content, the choice of teaching methods and the overall design of teaching. Yet, the differences are valuable resources. Through collaboration, teachers can inspire and learn from each other, work on their own weakness, and sparkle with new ideas, perfecting the original teaching concepts in a more scientific way and achieving a better effect in teaching and scientific research. It will produce a $1+1>2$ result. Collaborative teaching is an effective way in integrating teacher resources, complementing advantages and improving teaching quality. Nowadays, with the increasingly diversified approaches to cooperation, singular cooperative pattern cannot meet the demand of college English teaching any more. To realize personalized teaching in practice, improve the quality of college English teaching, English teachers in colleges and universities should be provided with opportunities for collaboration, stimulating their potential in all means, taking full advantage of teacher resources, and continuously exploring new collaborative approaches suitable for college English teaching in practice.

\subsection{Collaborative Approaches for College English Teachers}

Nowadays, there are many approaches to college English teachers' collaboration. We're going to have a look at some of them.

\subsubsection{Collaboration among Teachers within School}

Most schools practice tutorial system. Older and experienced teachers can guide young teachers and as the same time can improve themselves. Collaboration among teachers should be practiced during the whole teaching process, mainly involving pre-class collaborative lesson planning and design, during class collaborative teaching and after-class collaborative evaluation, and so on. A very important way to collaborate is collective working in preparing for the class, which can complement teaching contents, make the best of all sides and broaden teachers' horizon. Classroom teaching observation and evaluation can help teachers learn from each other. Regular teachers' meets can be held, at which, teachers can discuss problems they meet in teaching, such as students' individual differences and 
teaching patterns, seeking the best solution and achieving teaching innovation. Furthermore, research group is another import way in college English teachers' collaboration. It's very difficult for teachers to undertake a certain project all on their own, especially with the development of network technology. As a result, teachers have a greater need for collaboration in teaching and research so as to achieve resource sharing.

\subsubsection{Interschool Collaboration among Teachers}

There are various ways of interschool collaboration among teachers. For example, colleges and universities can hold inter-collegiate seminars about college English teaching at regular intervals, inviting scholars and experts from other colleges and universities to introduce the latest directions in scientific research, and sharing the fruits of teaching reform and scientific research. Send teachers to teaching reform experimental units for investigation and study, improving their capability in teaching and research, and seeking joint projects as well, thus achieving the goal of mutual development. Establish cooperative relationships among teachers from different areas for communication and exchange of information, thus keeping pace with the times. Hold teaching contests for teachers from different colleges and universities, in which, teachers can learn from and motivate each other. It's an effective way to achieve overall development.

\subsubsection{International Collaboration among Teachers}

With the popularity of the Internet, the transportation convenience and the introduction of foreign teachers, international collaboration among teachers has become possible as well. We can send our teachers out and invite foreign teachers in to realize international collaboration among teachers. Our school did just this: sending teachers to study and train abroad and inviting scholars and experts from Britain and America to give lectures; forming friendly relationships with colleges and universities in Britain and American; exchanging teachers to strengthen exchange in teaching and academy. It has achieved good results. On efficient way of collaboration is having a Chinese teacher and a foreign teacher work together to give classes. That's to say, one foreign teacher has a Chinese assistant, and they both show up in one class, with the Chinese teacher aiding class activities by explaining certain language points and the students' responses. As it shows, this kind of teaching collaboration greatly increases the students' interest and passion in taking part in classroom activities, thus achieving a much better teaching effect.

\subsubsection{Collaboration among Teachers Based on the Internet}

With the coming of the Internet era, the boundaries in collaborative teaching have disappeared.

Collaboration among teachers based on the Internet has become a major way for teachers to collaborate. Through the Internet, they can exchange teaching information, find and read a great deal of teaching materials at any time, refer to each other's course wares, observe each other's classroom teaching and provide feedbacks. There's no doubt that the Internet has provided numerous teachers with a promising media for collaboration, and also greatly improved the efficiency of it. There are many teaching websites, online seminars and new form of communicative tools to make use of by teachers, which makes it much easier for college and university English teachers to collaborate.

\section{Conclusion}

Individual strength is limited no matter in scientific research or teaching. Only through collaboration can we achieve a greater success. To practice high-quality personalized college English teaching, teachers need to take students' individualization into consideration, and improve their efficiency and quality in lesson preparation and lesson giving, avoid repetition work, and finally improve the level of college English teaching and better guarantee the teaching quality. Anyway, collaboration among college English teachers should be practiced at every stage in teaching. Only based on collaboration can College and university English teachers break through their own limits, form their unique teaching style and give their own personalized teaching in class, thus achieving a much better teaching effect.

\section{References}

Dai Wei-dong, \& Liu Chun-yan. (2004). New Developments in Learning Theories and the Shift of FLT Models. Journal of Foreign Languages, 4.

Hu Zhuang-lin. (2004). Individualization, Collaboration, Modularization, and Hypertextualization in College English Teaching Reform. Foreign Languages in China, 1.

Jiang Zong-zhen. (2006). Approaches to Collaborative Learning for Young Teachers in Colleges and Universities. Vocational Education Research, 1. 
Meng Lan. (2005). Collaborative Teaching between Old and Young Teachers. Social Scientists, 9.

Pei Yun-hong. (2008). Individualization and Collaboration in the Construct of English Teaching models. Educational Review, 4.

Wang Qiang. (2002). Action Research for Language Teachers. Foreign Language Teaching and Research press, Beijing. 